\title{
From Msimbazi River Valley to Mabwepande Settlement: The Resettlement Process and Its Challenges
}

\author{
Regina John*, Fredrick Bwire Magina, Emmanuel Fares Kemwita \\ Ardhi University, Dar es Salaam, Tanzania \\ Email: *reginajohn2000@gmail.com
}

How to cite this paper: John, R., Magina, F. B., \& Kemwita, E. F. (2019). From Msimbazi River Valley to Mabwepande Settlement: The Resettlement Process and Its Challenges. Current Urban Studies, 7, 399-426.

https://doi.org/10.4236/cus.2019.73020

Received: July 1, 2019

Accepted: September 16, 2019

Published: September 19, 2019

Copyright () 2019 by author(s) and Scientific Research Publishing Inc. This work is licensed under the Creative Commons Attribution International License (CC BY 4.0).

http://creativecommons.org/licenses/by/4.0/

\section{cc) (i) Open Access}

\begin{abstract}
The paper documents the resettlement process undertaken following the 2011 heavy rains in Dar es Salaam City, which adversely affected many people who lived in flood prone areas particularly in and along Msimbazi river valley. Within the resettlement process, challenges which were encountered by different actors during the resettlement process were investigated. With the use of qualitative and quantitative data, the paper shows that the resettlement of households from Msimbazi River Valley to Mabwepande followed a number of steps decided during the process with no pre-determined guidelines. The process largely centred around identifying those to be resettled, relocating them to the resettlement area and issuing alternative plots. The physical, economic, social, cultural and environmental dimensions of resettlement were less coherent in the process. Subsequently, the process resulted into both negative and positive outcomes, which are persistent until today. These include poor housing conditions, disruption of economic and income generating activities, unreliable social and technical infrastructure services, inability and or reluctance to develop the new plots and low living standards. However, high level of tenure security and certainty of being free from flood risk are some positive outcomes of the resettlement. The paper argues that the implementation of resettlement projects with no well-articulated process that takes care of the environmental, spatial, economic and social needs of the resettled population obscures the outcomes of the project. It therefore calls for caution when planning and implementing disaster led resettlement projects that necessary steps ought to be carried out to protect and enhance the wellbeing and livelihoods of those resettled apart from issuing alternative parcels of land.
\end{abstract}

\section{Keywords}

Resettlement, Flood Prone Areas, Msimbazi River Valley, Mabwepande 


\section{Introduction}

The urban poor are often the worse stricken by flood, earthquakes, landslides and cyclones and yet the most vulnerable to natural disasters for they inhabit overcrowded, marginal, unstable and dangerous land with no financial cushion or security (Cronin \& Guthrie, 2011). The decision to resettle flood victims or would-be victims is coherent with the nature and reasons for carrying out resettlement. Traditionally, decisions to resettle the population can be induced by development or by disaster (Artur \& Hilhorst, 2014; Wilmsen \& Wang, 2015). In the context of disaster related resettlements, prolonged disaster related events are affecting communities both in urban and rural areas. In urban areas, the occurrence of such events obliges governments to involuntarily relocate or resettle affected communities. However, resettlement is more often perceived as the worst option for it gives the impression that the affected community must be removed (Chan, 1995). Relocation, in this case, is unpopular as plans to relocate entire communities are costly mainly because, on the one hand, it requires an acquisition of alternative locations and the provision of housing for those resettled. On the other hand, it involves more disruptive effects (Baird \& Shoemaker, 2007). Basing on the foregoing argument and debate on resettlement, Arthur and Hilhorst (2013) discourse that many scholars tend to agree that spontaneous or voluntary resettlement is more likely to be more successful than the involuntary ones. Typical events which lead to involuntary displacement include flooding, management of natural resources for environmental protection or recovery, wars and conflicts in which people are displaced violently from their homes and are bereft of their possessions. In the case of natural disasters, resettlement is included at the post-disaster reconstruction stage. Populations are resettled when they cannot return to live at the original site, either because it has disappeared or because of prevailing conditions of risks that cannot be controlled by other means. In such situations, resettlement is, therefore, important in protecting lives and assets of those exposed to disaster risks. However, it is important that efforts to protect the lives and assets of those exposed to disaster risk should not expose them to other social and economic risks that the resettlement process could generate.

Over the last few decades there has been an increase in the number of hazardous events. Hydro-meteorological and climatological hazards are the most frequent causes of disaster events among all natural hazards globally (UNISDR, 2015). The most common meteorological hazards include heavy rains, storms/ hurricanes, droughts, tropical cyclones, rainstorm floods, heat waves and low temperature disasters (ibid). Such hazards often lead to adverse consequences on lives, properties and socio-economic activities. The 2019 Global Assessment Report on Disaster Risk Reduction (GAR) indicates that Multi-hazard disasters affected 88 million people in countries reporting through Sendai Framework Monitor in the period 1997-2017, with floods affecting 76 million people. Disasters stemming from natural hazards have displaced an average of almost 24 mil- 
lion people each year over the last decade and remain the main trigger of displacement.

Records show that over the last few decades, the majority of fatalities (more than 95\%) related with extreme events has been recorded in developing countries (UNEP, 2012). The Intergovernmental Panel on Climate Change (IPCC) confirms this and expounds that climate extremes cause higher death rates and greater impacts measured as portion of their gross domestic product (GDP) in developing countries (Handmer et al., 2012). As such, the impacts of natural hazards and, in particular, the disaster risk when compared on a global level, are unevenly distributed across the globe (UNDRR, 2019).

In Africa, hydro-meteorological events are key factors in triggering intensive disasters and crisis across all scales-illustrated by powerful weather systems like Cyclone Eline that traversed 2000 kilometres across Southern Africa, adversely affecting five million people in seven countries (Reason \& Keibel, 2004; Holloway et al., 2013). The 2010 West/Central Africa flood emergency that extended across 17 countries, including Liberia, Sierra Leone, Senegal, Cameroon and Chad adds to flood events in Africa (ibid). In 2002, heavy rains which struck East Africa also brought floods and mudslides that forced tens of thousands of people to leave their homes in Burundi, Kenya, Rwanda, Tanzania and Uganda (UN-Habitat, 2008; Douglas et al., 2008). Similarly, the low-lying river valleys along the Zambezi River in Central Mozambique experienced catastrophic flooding, the second such occurrence within two years, which was caused by heavy rainfall in the South Eastern Africa in early 2008 and up to 80,000 people were forced to displacement. This number added to tens of thousands of people already displaced from floods and cyclones during 2000, 2001 and 2007 (Macaringue, 2010; Stal, 2011; Artur \& Hilhorst, 2014).

Dar es Salaam City has equally been affected by flood events. For the past decades, flooding has been one of the natural events with significant impacts to city residents. These include, for instance, the El Niño associated events of 1997/98, which led to flooding that damaged buildings, infrastructure, properties and livelihoods. Other significant flood events that have pounded the city over the past two decades include those of 2000/2001, 2002 and 2006. In most cases, such floods were associated with the spread of malaria cases, cholera and diarrhoea (Conway, 2002). However, the recent flooding events, the flash floods of December 2011, 2013, and 2014, which not only led to destruction of private properties and basic public infrastructure but also resulted into displacement of thousands of city dwellers were the most notable severe floods in the city (John et al., 2014). The flash floods of 2011 led to the involuntary resettlement of some of the city residents from low lying areas along the Msimbazi valley to a peri urban non flooding settlement known as Mabwepande. The resettlement was planned by the government with an objective of addressing the risks and impacts associated with flooding to the residents.

However, literature shows that resettlement is a complex, multidimensional 
process with potentially very high negative impacts if not properly planned and implemented (Correa, 2011). When not properly planned, some of the resettled populations may opt to go back to the original settlements. In line with the preceding argument, John et al. (2014) account that some of the flood affected victims who were resettled in Mabwepande returned back to their original settlements. The foregoing implies that there were challenges associated with the resettlement process, those which were born to households, some of which necessitated them to go back to the flood prone areas. Although flood-led resettlement projects have been studied by a number of scholars, yet the resettlement processes and the associated challenges and opportunities accrued, are not clearly documented especially with reference to the 2011 flood aftermath, which occurred in Dar es Salaam. Knowledge devised from this study is expected to expand the existing literature particularly on involuntary flood induced resettlement programmes. It was interesting to know the challenges faced by the resettled households, which also inform why some decide to go back to their original areas within a specific context. Thence, the study narrows itself on the process used to relocate and resettle flood victims from their original residential flood prone areas [within and along Msimbazi/Jangwani river valleys] to holding centres and finally at the resettlement area.

\section{The Setting of the Study}

This study considers the Scudder and Colson $(1982,2012)$ theory on resettlement which provides four stages of settlement process. These include recruitment, transition, development and incorporation or handing over. The theory focuses on settlers' stress and their specific behavioral reactions in each stage. The founders of the theory provide that resettled individuals more or less react in predictable and broadly similar ways as the stress of displacement confines their response mechanisms. The main theoretical claim hinges on the fact that relocation, whether voluntary or compulsory, is a stressful experience, regardless of whether the process is voluntary or involuntary. According to the theory, the early phases of the resettlement process, i.e. the period just after the relocation, the transfer period and the first few years after resettlement during which the resettled population adjusts to the new environment, are the most stressful period. The theory further stipulates that resettled people rather behave in an innovative and risk avoiding ways during the late stage of resettlement process. Their behaviors and attitudes become flexible, which involve formation of new patterns and linkages in the resettled settlement. The innovation and risk taking behavior is a result of disintegration of the pre-resettlement of community social and economic assets. Moreover, the ability of the resettled households or community to re-establish social and economic assets and thus attain economic and social self-sufficiency is what determines the success and sustainability of resettlement (Scudder, 2012).

It is thus apparent that the success of any resettlement project, be it develop- 
ment or disaster led, depend to a large extent on its process. However, previous studies reveal that resettlement projects have marginalized and impoverished more people than they have enriched. Maghembe-Mushi and Lupala (2015) noted that population resettled by development induced projects negatively affected not only the displaced persons but also the welcoming population in the resettlement area due to poor planning. This was also observed by Lupala and John (2012) that displaced households suffered negative consequences in their new areas as compared to the original sites. Korrea et al. (2011) argue that a poorly planned and executed resettlement program can lead to social, economic, and cultural disasters even more serious than the natural disaster risks it is intended to prevent. In some situations, when not properly planned, some of the resettled populations may opt to go back to the original settlements. Haile et al. (2013) noted that some of the flood resettled residents in Ethiopia resorted to go back to the flood prone settlements and leave away the resettled areas. A similar situation was observed in Dar es Salaam whereby some of the flood affected victims resettled in Mabwepande were reported to return back to their original settlements (John et al., 2014). The behaviour of the resettled individuals to opt to go back to the original settlements may be regarded to as a risk avoiding behaviour, different from what is stipulated in the Scudder and Colson theory of resettlement. The returnees try to avoid risk of re-establishing livelihoods in new settlements.

\section{Methods}

Field activities for this work were conducted between April and August 2018. Basing on the objective of the study, that is, to understand the resettlement process, how flood victims were involved in the process and the ultimate outcomes of the process, a mixed research design was employed (Creswell, 2003, 2009). Emanating from the objective, the how- and what-questions according to Yin (2014) dominate and largely implied an investigative or exploratory research design (Creswell, 2007; Dawson, 2009; Stake, 2010). For this reason, facts, opinions and perceptions from targeted groups were sought. Some of space use related qualitative data especially on building construction had to be linked to the on-going housing development in order to devise and establish the extent of building construction over time and space. These are typical spatial outcomes of the resettlement process whose investigation required a quantitative approach (Dublin City Council, 2005, 2011; Boyko \& Cooper, 2011; De Folice, 2012; Lwin et al., 2012; Pafka, 2013). Thence, the empirical data covered semi-structured interviews mainly in the resettlement area. In this case, key informant interviews with local leaders at Ward and sub-ward levels as well as household interviews with people who were displaced from Msimbazi River Valley and resettled to Mabwepande were conducted. The household interviews involved a random selection of 176 out of the total 1004 households who were resettled in the area. Field visits and interviews were carried out with local leaders in order to understand 
the resettlement thread before seeking to explore the deep insights and experiences from the affected households. Moreover, semi-structured interview questions were deployed to obtain data and information from several experts in Dar es Salaam. These questions aimed at gaining general information relevant to flooding, displacement and resettlement as well as to obtain a range of insights on flooding issues. Key informants constituted officials from Kinondoni, Ilala and Temeke Municipal Councils, urban professionals from the Ministry of Lands, Housing and Human Settlements Development (MLHHSD) and Non-Government Organisations particularly the Tanzania Red Cross Society (TRCS).

Also, three focus group discussions with men, women and the youth were held to gather detailed information regarding the resettlement process, how the specific groups were involved and the changes they faced during the resettlement exercise. Handheld GPS was used to collect spatial data such as location of houses, and physical infrastructure facilities. Moreover, written reports and archival data on the resettlement process from the government and TRCS constituted secondary sources.

Data were analyzed both qualitatively and quantitatively. GIS-based methods for spatial statistical analysis was used to analyse the distribution of physical facilities such as buildings, roads, drainage, schools, health facilities, open spaces and other community facilities. Qualitative data from interviews and focus group discussions regarding the resettlement process and the challenges were analysed through content analysis.

The study area

The study was carried out at Mji Mpya, which is located in Mabwepande Ward at the outskirt of Kinondoni Municipality, 35 kilometers away from the Dar es Salaam City Centre (Figure 1). According to the 2012 National Population Census, Mabwepande Ward had a population of 25,460; 12,500 being males and 12,960 females (URT, 2013). Mapwepande is a peri urban ward, and formerly large part of the area was used for urban agriculture. Although the use of the land has been slowly changing from agriculture to residential uses, some pockets of undeveloped land are still used for urban agriculture. The Ward has a total area of 52 square kilometres and had population density of 489.4 inhabitants per square kilometres according to the 2012 National Population Census. The total number of households was 6800 (URT, 2013). The ward is composed of five sub wards namely; Mji Mpya, Mabwepande, Kinondo, Mbopo and Bunju $B$ (Figure 2).

The flood affected households were resettled in parts in the four zones referred by the locals as Kikwete Vision (Zone A), Nape (Zone B), Ridhiwani (Zone C) and Jakaya (Zone D) of Mji Mpya Subward (Figure 3).

\section{Findings and Discussion}

\subsection{Areas Flooded and Magnitude of Floods}

Areas which were adversely affected by flood during the 2011/2012 rains included 


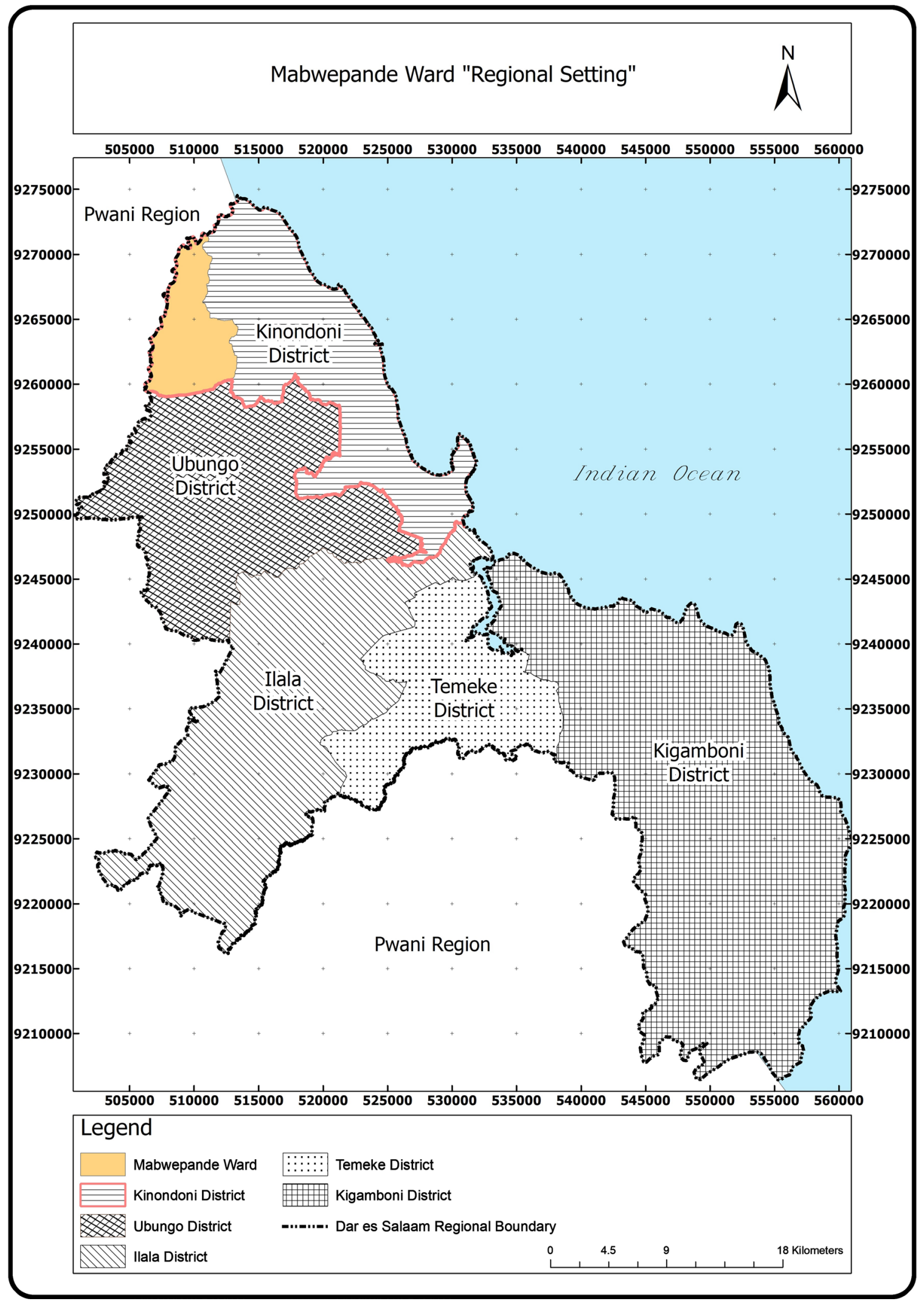

Source: Author from open data sources.

Figure 1. Mabwepande ward in Dar es Salaam. 


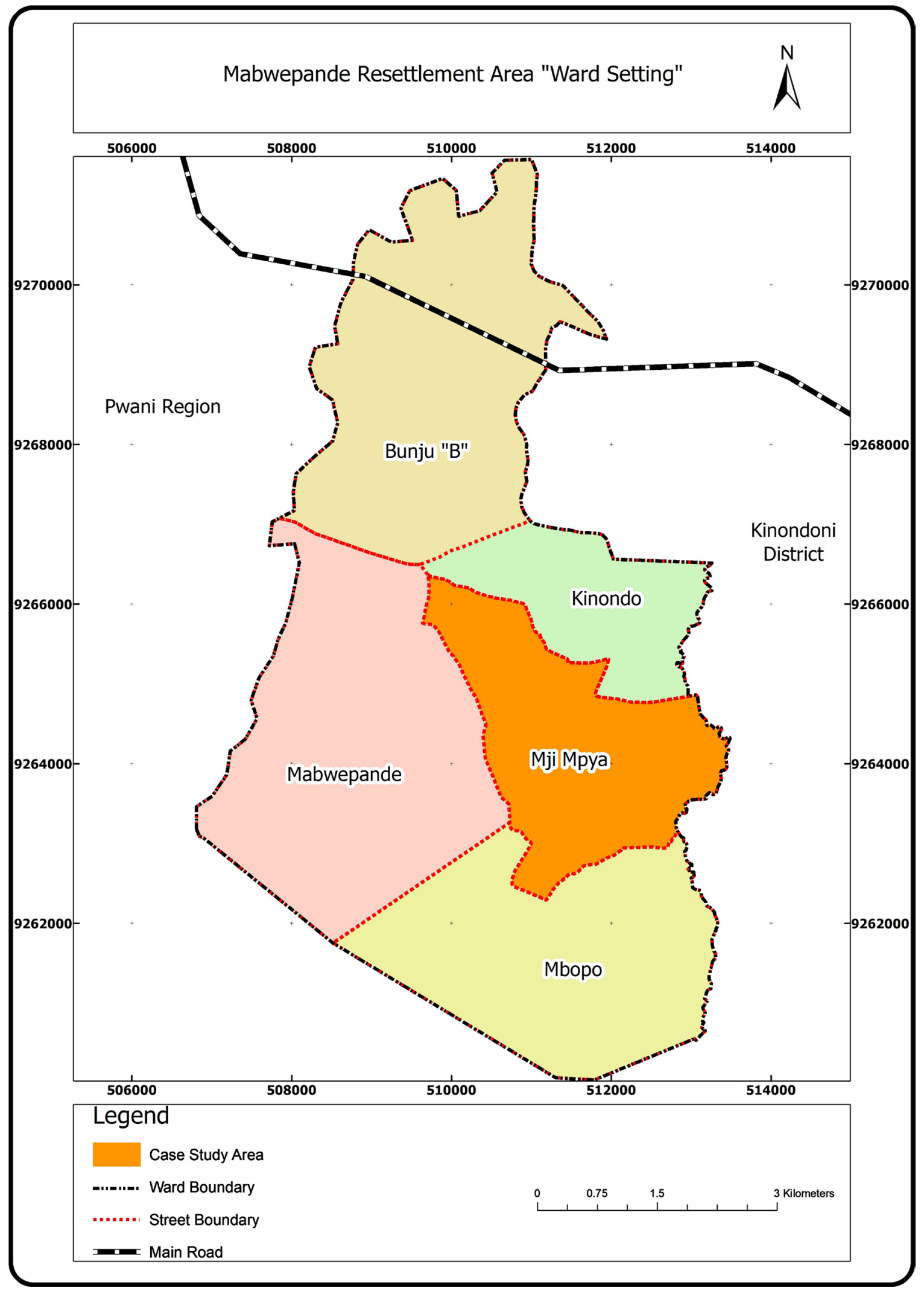

Source: Author from open data sources

Figure 2. Mji Mpya at Mabwepande Ward. 


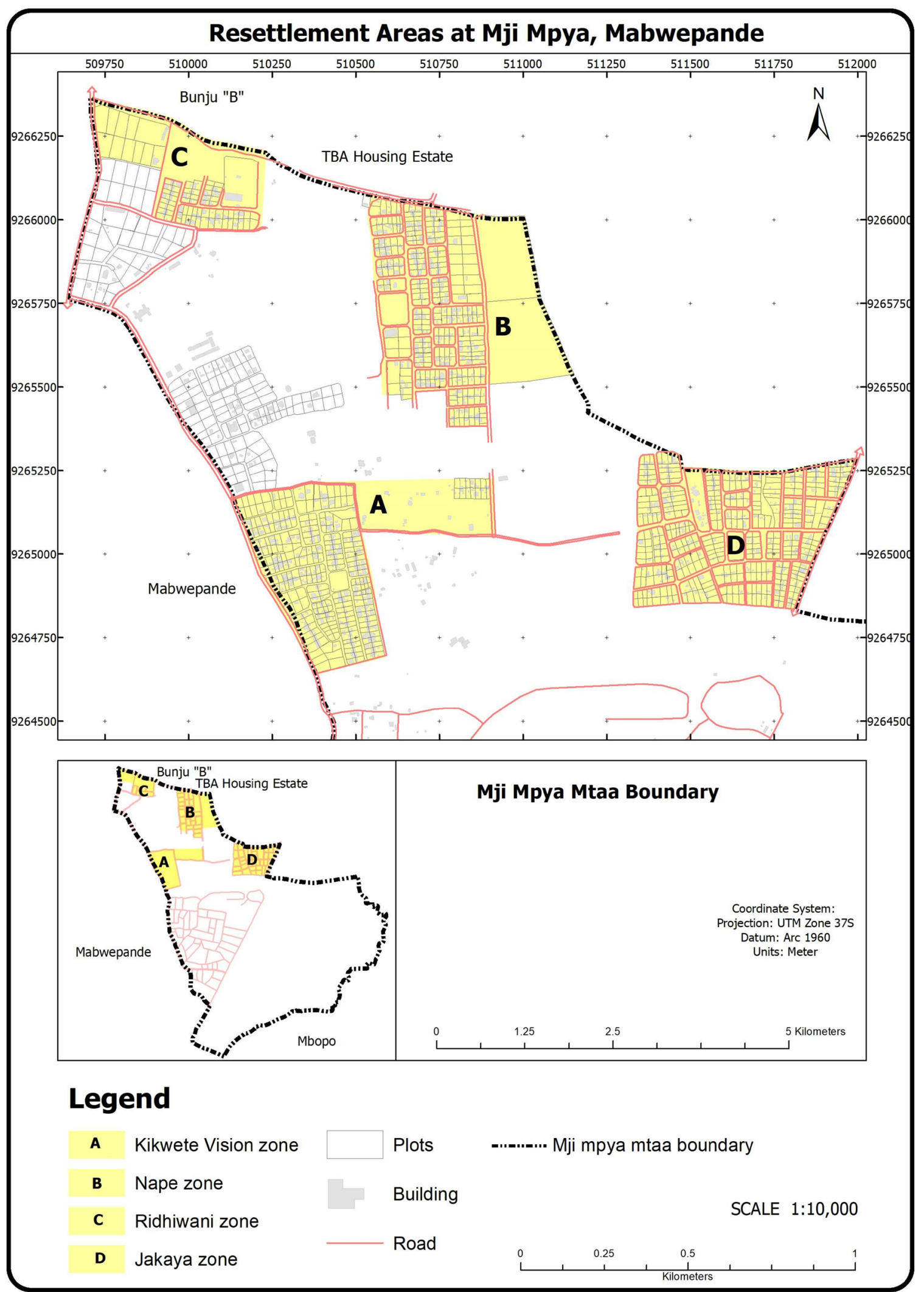

Source: Author's preparation, 2018.

Figure 3. Mji Mpya resettlement areas. 
those lying within the Jangwani/Msimbazi valley and other flood plains in the city of Dar es Salaam. The Msimbazi river valley, which runs from Pugu Hills down to the Indian Ocean, about 35 kilometres in length, constitutes three major rivers which are Ubungo, Sinza and Luhanga. The sides of the valley are generally occupied by residential buildings characterized by unplanned and un-serviced settlements. Usually, during the rainy season these settlements experience many problems related to floods. In particular, during the heavy rains [in April and May] water volume is high but maintains a low constant flow or dries up in the dry season. Also, it is worth noting that the largest percentage of residents in the river valley is composed of the low-income group who make a living through urban agriculture, petty business and unskilled labour. In this aftermath, which started in December 2011; 40 people lost lives; over 200 people were injured and approximately 10,000 people (about 2000 families) were displaced. The total number of affected people was estimated at above 50,000 (about 10,000 families), from all the three Municipalities of the Dar es Salaam city, by then ${ }^{1}$, which were Temeke, Ilala and Kinondoni. Damages from floods included demolition of houses and destruction of other domestic properties, submergence of houses with water and siltation (see Plate 1 and Plate 2). Communicable diseases

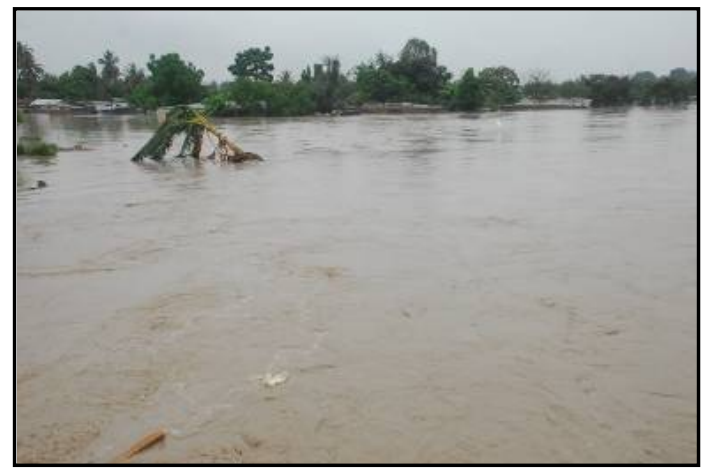

Source: Tanzania Red Cross Society, 2018.

Plate 1. Msimbazi valley and flood plain.

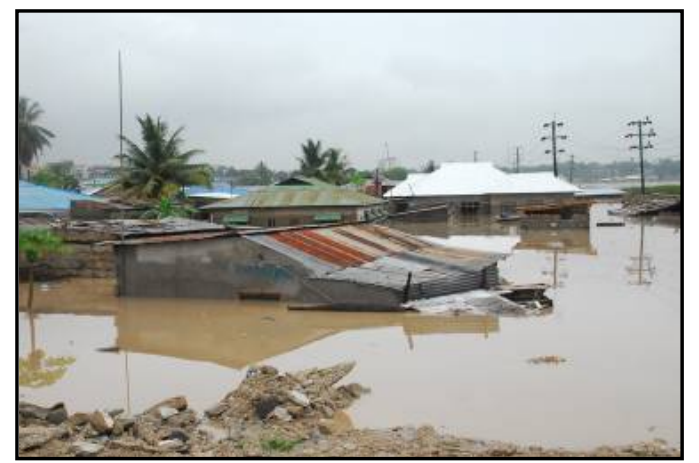

Source: Tanzania Red Cross Society, 2018.

Plate 2. Flooded/submerged houses.

${ }^{1}$ Currently, the city comprises five Municipalities namely; Ilala, Kinondoni, Temeke, Kigamboni and Ubungo. 
such as cholera, malaria and dysentery were also prevalent during the rainy season.

The flood incidence at Msimbazi river valley in 2011 in Dar es Salaam resembles other similar events in the world. In the history of Kamgar Putala, India, following a disastrous flood event in August 1997, six slum pockets situated along the banks of the river Mutha between Kamgar Putala and Dattawadi were adversely attacked; submerging 847, nearly half of all the houses (Cronin \& Guthrie, 2011). In 2001, 2007 and 2008 heavy rains caused flooding along the Zambezi River in Central Mozambique. In 2007 another tropical cyclone, Cyclone Favio, increased the number of homeless people in Mozambique following the flooding of the Zambezi River. The floods of 2007 alone displaced over 100,000 people and an estimated 50,000 people were evacuated to "accommodation centres". Affected people lost their homes and livelihoods as well access to medical facilities, sanitation and safe drinking water (WHO, 2007; Stal, 2011).

In summary, flooding in cities is largely associated with settlement development along river banks as it is the case for the Msimbazi river valley and its tributaries. Msimbazi valley is defined by Dar es Salaam Master Plans of 1978 and the draft 2016 as a hazardous [flood prone] area dedicated for recreational purposes. Because of its proximity to the CBD and weak urban governance mechanisms, the area has always been invaded and used for residence as opposed to existing urban development plans. Frequent floods cause deaths and loss of properties to dwellers. Flood coping measures such as temporary relocation is common though the actions do not address the flooding problem.

\subsection{The Resettlement Process}

The entire process involved two main phases: relocation and the actual resettlement. Relocation phase involved moving people from flood prone areas to holding centres, mainly public buildings. The resettlement encompassed moving flood victims from holding centres to the resettlement area at Mji Mpya, Mabwepande Ward.

\subsubsection{Relocation Phase}

The relocation phase of the flood victims from Jangwani/Msimbazi flood plain involved a number of steps and activities. Rescue operations were largely performed by the Tanzania Red Cross Society (TRCS), the Tanzania People's Defence Forces (TPDF), the Fire Brigade, the Department of Disaster Management of the Prime Minister's office, Municipal Councils and the general public. The rescued individuals were accommodated in temporary shelters in holding centres established in each Municipality. In Ilala Municipality, two holding centres were established; Uhuru Mchanganyiko Primary School and Benjami Mkapa Secondary School for women and men flood victims respectively. In Temeke Municipality, the flood victims were accommodated at Mgulani military base and at sub-ward offices while in Kinondoni Municipality a holding camp was 
established at Magomeni Primary School.

During the rescue phase, the general public and individuals used traditional gears such as ropes and canoes while government agencies such as the TPDF and international organizations particularly TRCS used advanced equipment's including boats and helicopters. The holding centres were mainly public education institutions particularly primary and secondary schools as well as godowns (see Plate 3). The holding of flood victims in public places is a common experience in countries which have experienced involuntary resettlement programmes due to natural calamities. In India, Mozambique, China, South Africa and Malaysia governments largely held flood victims in public buildings except in cases where such buildings could not accommodate the affected communities (Cronin \& Guthrie, 2011; WHO, 2007; Stal, 2011; Artur \& Hilhorst, 2014; Wilmsen \& Wang, 2015; Dixon \& Ramutsindela, 2006; Chan, 1995).

Local institutions, private firms and other international organizations such as the International Federation of Red Cross and Red Crescent Societies (IFRC), UNICEF, UNHCR, Save the Children USAID and the general public also participated in provisioning of humanitarian services and first aid during the relocation phase. In particular, tents, water, mosquito nets, soaps, sanitation and health services particularly on cholera preparedness, were provided. Other relief services encompassed clothes, food, drinks and other home-based needs amounting to a total of 14,213 items. To support the foregoing, majority of the household interviewed, which is about 88 percent indicated that they received support from various external sources, which helped them during the displacement process, while only 12 percent indicated to have not received support. Identification of the flood affected persons, the who, for resettlement concluded the rescue operations. In this exercise, specific criteria including proof of housing ownership, state of the building in terms of the extent of damage, i.e. partially or totally destructed aided the identification of the population to be resettled. In that view, all tenants were neither considered for resettlement nor for compensation.
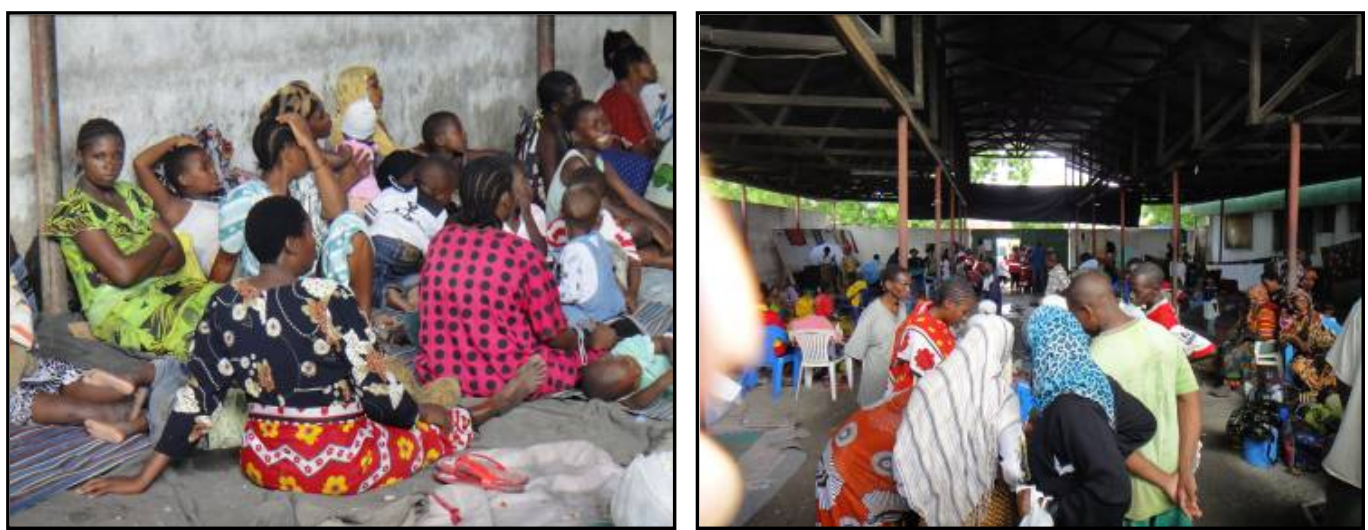

Source: Tanzania Red Cross Society, 2018.

Plate 3. Displaced populations at temporal holding centres. 


\subsubsection{Resettlement Phase}

In principle, once the who of resettlement are determined, the where to must also be decided. In this resettlement programme, the phase involved identification of the resettlement area, preparation of the resettlement scheme, provision of basic social services, plot allocation and programme termination.

\section{Planning and governance}

The Ministry of Lands, Housing and Human Settlements Development (MLHHSD) was held responsible to provide the resettlement area, which could instantly accommodate flood victims. Mji Mpya sub-ward in Mabwepande Ward, already planned to accommodate various land demands and needs of individuals and institutions as part of the peri-urban development programme, was offered. In particular, the area was planned and designed to accommodate mainly plots for residential, institutional, commercial and other uses. The Institute of Finance and Management (IFM) and the Dar es Salaam Institute of Technology (DIT) had their areas set aside in this area. Furthermore, about 200 residential plots of different sizes were already provided. Thence, the area was given as a remedy and alternative area for the flood affected people. Later, the layout plan was handed to Kinondoni Municipality in order to sub-divide the plots in small sizes, which had to be issued to 622 identified flood victims. The sub-divided plots were then distributed to each Municipality according to the identified number of households to be resettled. Ilala Municipality, which was severely affected, was given the first priority and the plot allocation was done in two groups. The first group involved 499 flood affected households who were allocated plots in the resettlement area in March 2012 in five phases as Table 1 shows.

After the preparation of a resettlement layout and allocation of plots, TPDF, TRCS, DMD, Regional Commissioner's Office and respective Municipalities played a role of handing over the plots and relief services to the households at Mabwepande. The first batch of the households resettled at Mabwepande were allocated new plots as well as tents for temporary accommodation.

In the second group, 123 affected households from various parts of the City including Gongolamboto, Majohe, Kinyerezi, Tabata Upanga West and Charambe wards as Table 2 presents, were allocated plots by May 2012. The households in

Table 1. First batch plot allocation to affected households by phase.

\begin{tabular}{ccccccc}
\hline Phase & I & II & III & IV & V & Total \\
\hline No. of plots issued & 138 & 273 & 21 & 25 & 42 & 499 \\
\hline
\end{tabular}

Source: Ilala Municipal Council, 2018.

Table 2. Second batch plot allocation to affected households.

\begin{tabular}{cccccccc}
\hline Ward & $\begin{array}{c}\text { GongolaMboto/ } \\
\text { Ulongaoni }\end{array}$ & Majohe & Kinyerezi & Tabata & $\begin{array}{c}\text { Upanga } \\
\text { West }\end{array}$ & Charambe Total \\
\hline No. of Plots issued & 2 & 1 & 4 & 50 & 42 & 24 & 123 \\
\hline
\end{tabular}

Source: Ilala Municipal Council, 2018. 
this batch were allocated plots but did not receive tents for temporal accommodation due to the acute shortage of the facility.

\section{Shelter associates at Mabwepande}

With respect to the preparation of layout plan to accommodate flood victims we argue that preparation concentrated more on maximizing space for residential premises than on other supporting land uses. This failure has resulted into a number of physical, spatial and social burdens to residents at Mabwepande.

This study discovered that the plot sub-division was done without making a critical site analysis especially on the nature and the characteristics of the proposed resettlement area. As such, some plots were located within or along river valleys and as a result, houses built are subjected to heavy erosion and are in a higher risk of being washed away (Plate 4). Equally, those plots allocated within valleys experience sheet or gully erosion (see Plate 5 ) and these scenarios are more peculiar during the rainy season. A similar trend was observed on some roads within the resettlement area.

In terms of shelter provisioning, the government with support from various actors including donor agencies provided tents for temporal accommodation

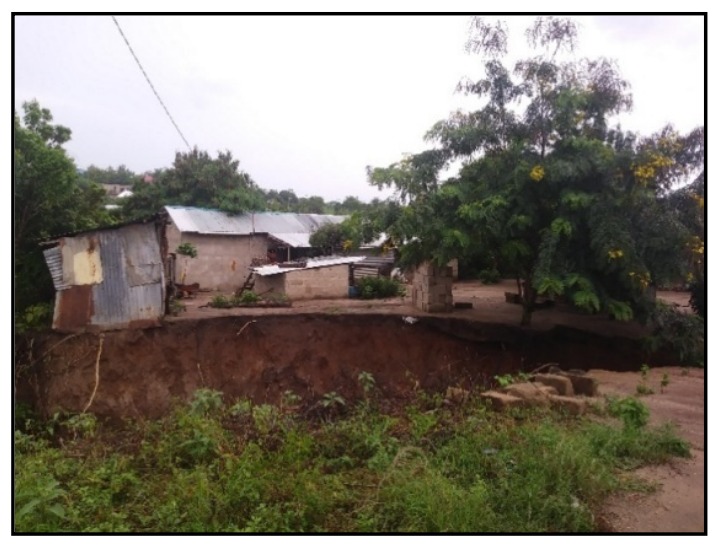

Source: Fieldwork at Mji Mpya sub-ward, March 2018.

Plate 4. Plot besides a river valley.

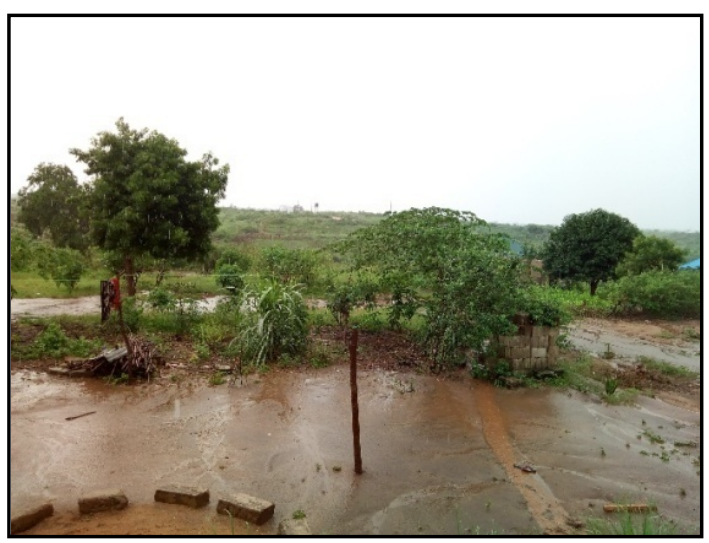

Source: Fieldwork at Mji Mpya sub-ward, March 2018.

Plate 5. Plots in a river valley. 
(see Plate 6). The Tanzania Red Cross supported the construction of 680 tents providing shelter to about 3400 people at the re-settlement site. It is worth taking note that 300 out of the 680 constructed shelters were completely funded by own resources (DREF) while the rest (380 shelters) were jointly funded by the National Societies (NS), TRCS and the Government authorities. The military provided much of manual labour required for the construction of the temporary shelters, latrines, and bathing shelters. Records show that a total of 56 temporary communal latrine drop holes and 56 bathing shelters were constructed with a support from DREF and UNHCR. The provision of tents went hand in hand with the handover of other building materials and relief services. Similarly, the resettled population received home-based utensils such as plastic buckets, plates, bowls, cups, glasses, bar soaps, blankets, mosquito nets and mattresses amounting to 6393 items.

Limited building materials were provided to flood victims by the President of Tanzania and other donor agencies. The President's Office offered 100 bags of cement to each household. Other donor agencies provided four pieces of timber and four pieces of iron sheets to facilitate the house construction. The provisioning of only few materials for house construction is distinct from the approach implemented elsewhere with respect to supporting the resettled households to secure shelter after resettlement. For instance, flood victims resettled from the lower Zambezi in Mozambique following the 2007 flood were sufficiently provided with building material including cement, roofing material, doors, and windows which facilitate the construction of modern houses (Artur \& Hilhorst, 2014).

Consequently, the study found out that majority of the resettled households did not use the building materials provided to construct houses. Some of the households sold the materials to willing buyers claiming that the materials were not sufficient for the construction and completion of modern houses, while others argued that they lacked places to store the materials. Some of the resettled households claimed that the selling of the building materials assisted them to cope with life after the resettlement. As a result, until 2018, six years after the resettlement, many flood affected households who were resettled to Mabwepande had not
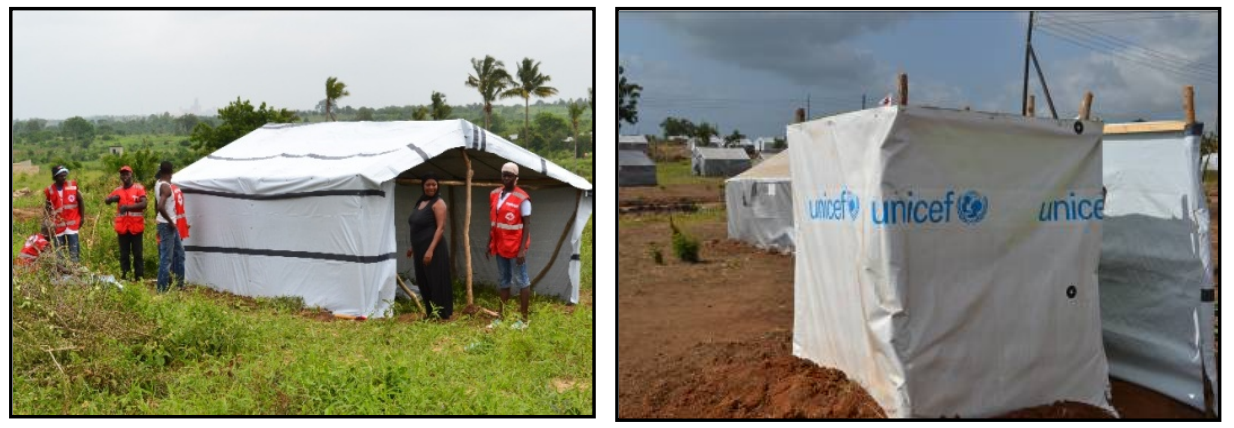

Source: Fieldwork at Mji Mpya sub-ward, March 2018.

Plate 6. Tents and toilets/bathing shelters constructed at Mabwepande. 
built new houses using the support provided by different government agencies and donor communities. Physical observation of the resettlement area to determine the extent of plot development revealed that large proportions of the plots allocated to the resettled households are still undeveloped. A total of 1072 plots allocated to resettled households were analysed and results indicates that 584 (54 percent) plots are developed while 488 (46 percent) plots are un-developed. The developed plots include those with partial/or incomplete house structures as well as temporary houses, referred by locals as "full suit" . Further analyses of the quality of building structures in two of the zones revealed that majority of the households are accommodated in uncompleted or still under construction buildings (Figure 4).

\subsection{Challenges of the Resettlement Process}

\subsubsection{Weak Rescue Gears and Institutional Overlaps}

This study observed that during the rescue and relocation of flood victims, inadequacy of modern tools and overreliance on traditional gears (ropes and canoes) affected the process. The study further observed that there was overlapping powers and power relations among many institutions involved, which also affected the process. In this regard, professionals from the respective municipalities did not fully take part in the process as were partially involved during the relocation to holding centres and virtually disappeared during the resettlement to Mabwepande. Failure to take part also culminated from lack of financial budget and gears required for rescue operations. Consequently, the relocation and resettlement processes were slowed down resulting into more fatalities to flood victims. It was also found out that some stakeholders who were not well-wishers but entrusted to be in charge of certain sections in the resettlement programme attempted cheating, particularly in distribution humanitarian services distribution for personal gains

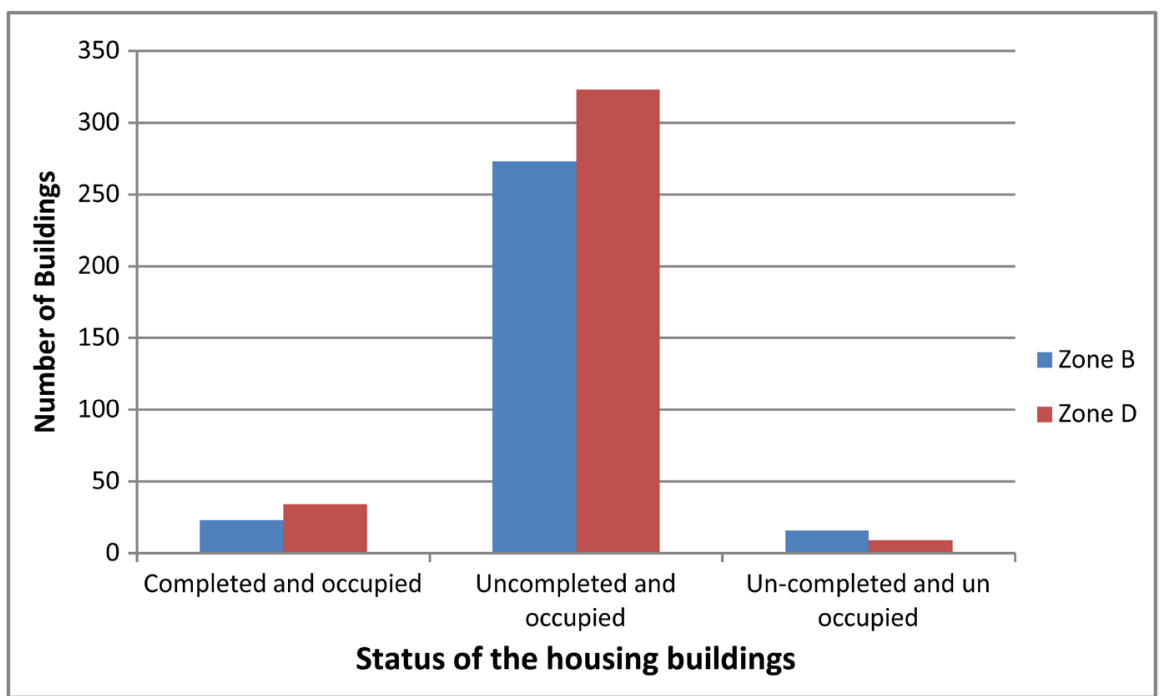

Source: Field observation, 2018.

Figure 4. Status of the housing buildings in the resettled area.

${ }^{2}$ Houses are constructed using iron sheets in both the walls and roof. 
at the expense of the flood victims. As a result, the flood victims were denied their rights to adequately and timely access and benefit from the support services offered. Another scenario which revealed power rationality was the decision whether or not to include tenants in the resettlement phase. It is worth noting that, only those owners who were accommodated in the government established relocation centres were considered in the resettlement. House owners who shifted to relatives and friends during the flood event were not considered. Tenants who were also affected with the floods were not considered in the resettlement. Tenants were, therefore, subjected to a precarious period in the days after the floods, not knowing whether they would be confirmed by their house owner and consequently receive any assistance. Being counted and becoming known, therefore, became a vital practice to be involved in and tenants became increasingly aware of the restrictions that accompanied their tenure status.

Respondents from the MLHHSD and the Regional Commissioner's office had one common say about the legibility of the tenants in land allocation at Mabwepande. The two sides did not find tenants eligible for the plot allocation. Both the MLHHSD and the Regional Commissioner's office were of the opinion that tenants could go and rent houses or rooms in other places because they were just renters and the law does not recognize their tenure.

The opinions by the officials from the Ministry of Lands and those from the Office of the Regional Commissioner contradict the statement given by the President ${ }^{3}$ while addressing the public about the aftermath. Being neutral and justice he denied the exclusion of tenants in the allocation process by stressing that they also belong to the nation and that the government should be concerned with their plight and should not be left to suffer. Furthermore, the government and every good wisher needed to support as well as taking care of them.

The foregoing represents power and power relations. It also reveals a political and legal vacuum regarding "tenants". It also translates tenants as a group of population, which is disregarded with respect to tenure issues as it lacks recognition and acknowledgement by the state.

\subsubsection{Hostile Physical Environment in the Resettlement Area}

Evidently, the flood victims from flood prone areas were resettled to almost undeveloped and unoccupied area. During focus group discussions with the youth, male and female respondents, it was argued that the surroundings of resettlement area was generally hostile for human survival. The largest part of the area and its surroundings comprised thick bushes, shrubs and grasses which inhabited hostile animals. A discussion with a group of women revealed that the resettlement area had thick forests with tall grasses, snakes, hyenas, scorpions, centipedes and other kinds of dangerous animals and insects. This environment was dangerous to both the youth and the adults.

It therefore came out that the physical environment at which the flood victims

${ }^{3}$ The fourth President of the United Republic of Tanzania (1995-2015). 
were resettled was unfavourable. There was inadequate preparation of the site and as a result, the temporary shelters (tents) were laid on top of grasses. To address the challenge, the resettled households, particularly men, had to clean the site by slashing the grasses so as to reduce the risks of being bitten by hostile animals and insects. Women had to provide pieces of clothes that were laid on the ground, beneath the mattresses.

Supporting the issue of hostile environment at the resettlement area, men, during the focus group discussion argued that the resettlement area is located close to Mabwepande forest reserve and thus it was very usual to hear or see wild animals from the neighbouring areas particularly from the forest. Consequently, the resettled households had to spontaneously cope with the horrifying environment including monitoring their own movements and being careful especially during night hours.

\subsubsection{Limited Space for Accommodation versus Large Family Sizes}

The tents availed to the resettled households provided limited space of accommodation, which did not match with their family structures. The average household size ranged between four and six people; majority of the households comprise a father, mother, children, relatives of different sexes and sometimes in-laws. During the interviews, the resettled households argued that after being brought at Mji Mpya, some found tents installed in their plots while others received bare plots with no tents installed. Nevertheless, only one tent was provided per household and thus all household members had to sleep therein regardless of their differences in sex, age or other socio-demographic characteristics. Some of the households who did not receive tents in the first day had to spend the night in the open-air.

In the following day(s), the households had to sub-divide the tents using pieces of clothes or curtains to separate different spaces according to gender and age, but still could not suffice the space needs of the families. A remedy to this was to construct external building structures mainly made of woods and dilapidated corrugated iron sheets, locally referred to as full suits, so as to host the youth and in-laws. Part of these building structures also served as kitchens and stores. The tents were, therefore, left to be used by the household heads (fathers), mothers and little children. It was observed during the study that the full suits are still in use. The on-going construction and use of full suits is an indication of inability of the majority of households to afford constructing houses using conventional building materials. The households also argued that lack of employment opportunities in the resettlement area is the main factor that hinders them from progressing in the construction of modern houses. As a result, the largest proportion of plots in the resettlement area are still undeveloped while others contain temporary structures.

\subsubsection{Insufficient Provisioning of Public Facilities and Services}

Access to health and education services is a challenge in the resettlement area. 
The study noted that, during the project hand over, only a nursery, a primary and a dispensary were operational. High level health facilities such as health centres and hospitals are lacking within the reach of the majority as the services are accessed at distant locations from Mabwepande. A health facility at a level of a dispensary is available in the resettlement area. However, the facility offers services of lower level, has limited medical equipment's as well as medicines. It was also realised from the focus groups discussions conducted that the dispensary does not provide services throughout a week as it closes on Sunday. Besides, maternity services are not provided, and that was raised as a major concern by the households. Households thus face challenges to access health services outside the resettlement area due to long distances, unreliable and high cost of transportation. The situation is more pathetic in case of emergency illnesses, which require immediate medical attention at higher level health facilities.

The resettled households also face challenges in physically accessing education facilities. The resettlement area has no secondary school; as a result, students walk at least two hours to access a school located in a neighbouring settlement. The challenge is compounded by lack of public transport in the area. Use of private means of transport, specifically motorcycles, which are the most common means of transport in the peri-urban areas, is unaffordable to the majority due to high costs involved. It was revealed through household interviews that a single route by a motorcycle costs an average of Tanzanian Shillings 1500, which is approximately US $\$ 0.7$. The challenge of high transport costs in accessing secondary schools was also reiterated by members of focus group discussions held in Mabwepande. It was noted from the discussions that it costs up to Tanzanian Shillings 4000 , which is approximately US\$ 0.9 for motorcycle transport, which is unaffordable to the households. The foregoing translates to the limited physical accessibility of the resettlement area, which is aggravated by poor road infrastructure and lack of public transport. Improvement of road accessibility and introduction of public transport was therefore mentioned to be an urgent need to the resettled households.

The challenge of limited physical accessibility in the resettlement area affects not only the school going children but the adults as well. It was noted through household interviews and focus group discussions that households walk an average of one kilometre distance in order to access public transport services. Alternatively, one has to first use a private means of transport, i.e. motorcycle before can access the public transport. The cost of hiring a motorcycle, one route, to the public transport destination ranges between Tanzanian Shillings 1500 (approximately 0.7 US\$) and 2000 (approximately 0.9 US\$). Such costs are relatively high taking into account the fact that about 40 percent of the households live under extreme poverty, i.e. below the international poverty line of US \$1.9 ppp per day as per the household interviews conducted.

Access to recreation facilities, specifically play grounds by children was also 
observed to be a challenge. The study reveals that recreational facilities and play fields were not sufficiently provided in the resettlement plan. The youth affirmed that except at the primary school and in some few blocks, large part of the resettlement area is not provided with play grounds. Consequently, children and the youth use undeveloped plots as play grounds. The undeveloped plots are however not safe as they contain hazardous materials such as thorns, edged grasses as well as dangerous insects. Artur and Hilhorst (2014) account differently on the Mozambican experience whereby the government encouraged resettlement by providing social infrastructure such as brick-built schools, potable water and health care to the resettlement centres. It also designed and implemented, in partnership with NGOs, donors and the private sector, agricultural seed vouchers and fairs, and the affected were advised to form associations which would link up with markets and with different governmental and NGO interventions.

\subsection{Building Conditions and Tenure Security}

\subsubsection{Plot sizes and House Designs}

Residential plots in the resettlement area were organized into four zones namely, Ridhiwani, Jakaya, Nape and Kiwete Vision with the size of plots limited to 300 $\mathrm{m}^{2}$. The plots are therefore relatively small, meant for high density residential development. Within the small plots at Mabwepande, the government expected flood victims to construct permanent houses whose house designs were prepared by the Kinondoni Municipal Council. One design constituted a main house with four bedrooms, lounge, kitchen, dining, WC and a shower and the second was a servant quarter with two bedrooms, a sitting room, shower and WC. The proposed design meant that two houses were to be built in a single plot, a consideration, which seemed to be not feasible given the economic status of the resettled households. As a result, a local Community Based Organisation, Centre for Community Initiatives (CCI) negotiated the proposed house designs and came up with a hybrid (a new) house design, which comprised two bedrooms and a kitchen. However, during field visits and interviews with households it was found out that none of the recommended designs was implemented by the resettled households. As such, individuals have constructed and are constructing houses using their own and different house designs. This study realized that the issue of cost was a challenge for the resettled households to afford constructing a three self-contained bedrooms house and an external two bedrooms' house.

Nevertheless, the high density plot sizes provided to the resettled households imply a constrained opportunity of carrying out some of the livelihood or income generating activities related to urban agriculture such as vegetable production and poultry keeping, which were common in the flood prone areas with no possibility of offering. Experience on resettlement projects elsewhere shows that resettlement projects ought to consider provisioning of adequate land to sustain the livelihoods of the resettled households for it to be successful. Artur and Hilhorst, (2014) noted that the involuntary resettlement of flood victims from the Zambezi River valley in 
central Mozambique was successful as each household got a plot with $120 \mathrm{~m}^{2}$ (30 $\mathrm{m} \times 40 \mathrm{~m})$ and about one hectare of land for agriculture. The pieces of land provided was in addition to other support including provisioning of building materials. It therefore implies that, although the resettlement was involuntary, the government applied some pull factors such as providing plots and building materials for house construction but also land for supporting livelihood activities.

\subsubsection{Tenure Security}

Concerning tenure security, the resettled households argued that they feel safer and more secure in the resettlement area than in their original areas. With exception of the few households who have their plots located in small valleys, large proportion of the resettled households are not worrying of being affected by floods as it used to be in the original settlements along the Msimbazi River Valley. Similarly, in terms of tenure security, households in the resettlement area expressed their gratitude and satisfaction of access to secure land tenure. Although it was noted through the household interview that, the resettled households are yet to obtain title deeds for the land occupied at Mabwepande, the fact that the plots were provided by the government gives the households a security of tenure. This is opposed to the situation in the flood prone areas where the plots were informally owned with no state recognition. The resettled households argued that the land owned informally along the Mzimbazi Valley was associated with risks of eviction by the government. That was in addition to the risks associated with flood impacts, which include destruction of properties.

From the foregoing, it is apparent that the resettlement of flood victims from Msimbazi river valley to Mabwepande, not only provided a safe living environment but also ensured security of tenure.

\subsection{Housing Condition in the Resettlement Area}

The housing condition in the resettled varies among the households. Some households live in incomplete houses while others live in temporary structures (Plate 7, Plate 8). The temporary house structures, locally referred to as full suits are built with dilapidated corrugated iron sheets, both the walls and the roof, as seen in Plate 8. Spaces or rooms in the full suits houses are partitioned by curtains and usually include one bedroom for the household heads and one or two more rooms for other members of the household. Other housing facilities such as pit latrines, kitchens and bathrooms are constructed as separate structures.

A detailed analysis of the housing conditions in the resettlement area revealed that large proportion of the houses are occupied but incomplete. For instance, in Zone $\mathrm{B}$, which has a total of 312 buildings, 273 buildings, equivalent to $86 \%$ are incomplete but occupied, while 23 buildings (7\%) are completed and occupied, and the remaining $16(5 \%)$ are under construction and not occupied. Similarly, in Zone D, which has a total of 332 plots, 323 buildings (about 97\%) were occupied although they are incomplete, while 34 buildings (1\%) are completed and 


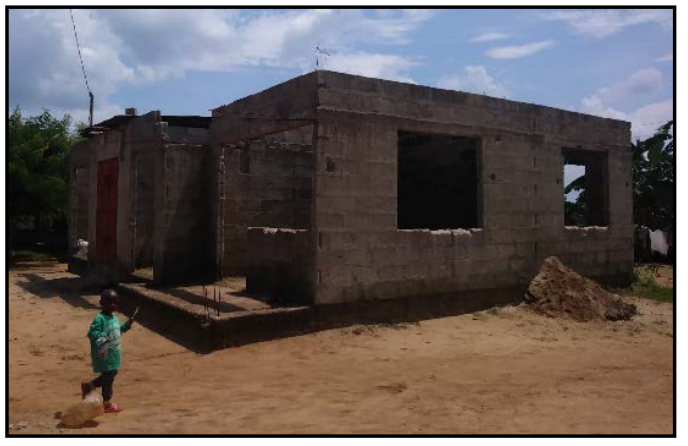

Source: Fieldwork at Mabwepande, 2018.

Plate 7. Semi-completed house.

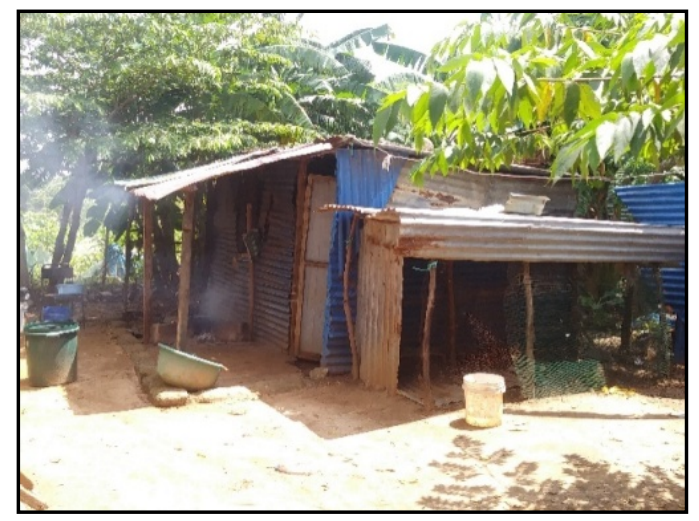

Source: Fieldwork at Mabwepande, 2018.

Plate 8. Corrugated iron-sheets hut (full suit).

occupied and the remaining 9 buildings (2\%) were under construction and un-occupied.

The households' occupation of incomplete and temporary structures reflects their low levels of affordability to construct modern houses. The study underscores the importance of incremental house construction, which is common to low income individuals such as those resettled in Mabwepande.

Nevertheless, there also exist some houses which are decent and in good condition at Mabwepande resettlement area. However, field results from interviews indicated that those houses do not belong to the resettled households. Instead, some plot owners who were resettled in the area sold their plots to willing buyers who constructed modern house structures as shown in Plate 9. The buildings are constructed using modern building materials, which include cement bricks for the walls and iron sheets or tiles for the roofs. The buildings are also installed with infrastructure facilities electricity and water.

Apart from the incomplete, the temporary as well the few modern houses, which characterise the housing situation in the resettlement area, some plots are completely vacant and seemed to be unattended by occupiers (Plate 10). Other plots contain foundations only (Plate 11).

Analysis on the extent of development of plots allocated to the resettled households 

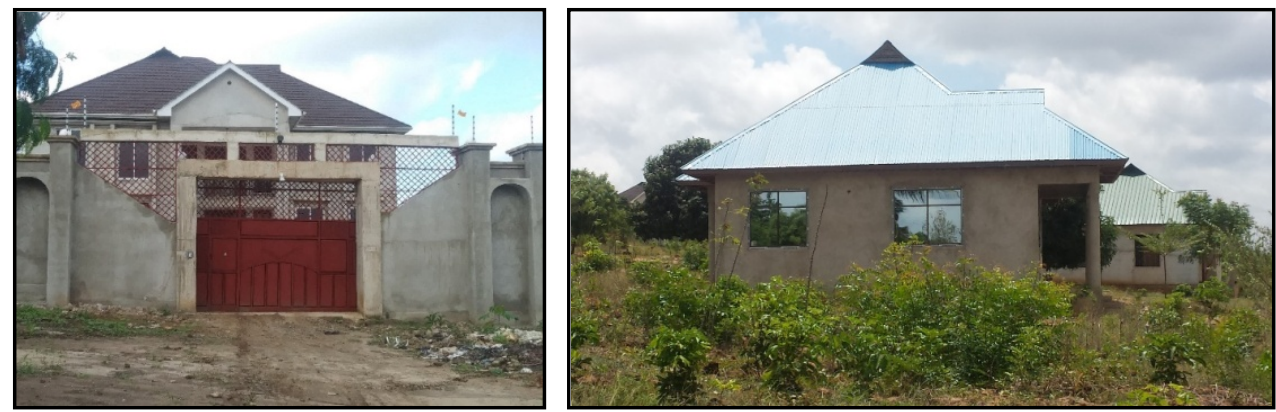

Source: Fieldwork at Mji Mpya-Mabwepande, 2018.

Plate 9. Modern houses in the resettlement area.

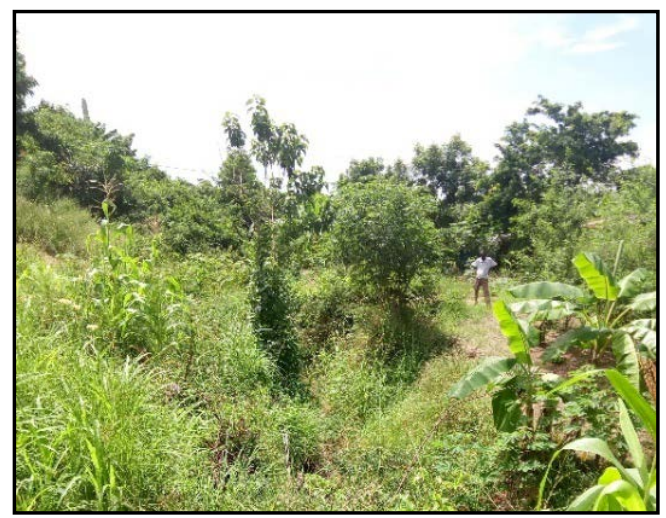

Source: Fieldwork at Mabwepande, 2018.

Plate 10. Unattended plot.

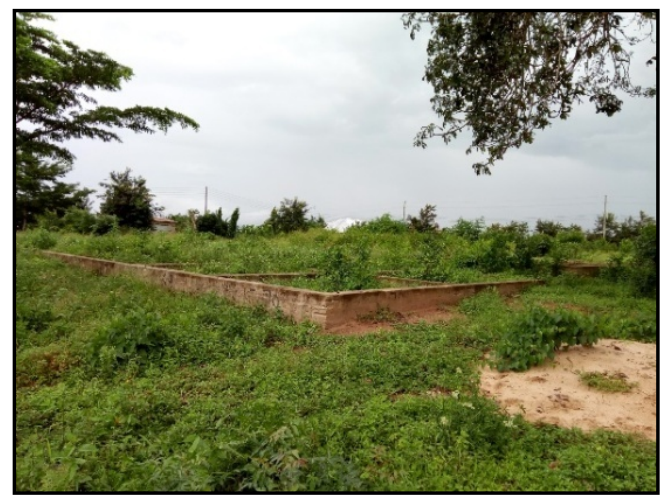

Source: Fieldwork at Mabwepande, 2018.

Plate 11. Plot with a foundation.

shows that large proportion of the plots is still vacant or undeveloped. A total of 1072 plots allocated to resettled households were analysed and results indicates that 584 (54\%) plots are developed, either partial or full, while 488 (46\%) plots are undeveloped. Further analysis of the extent of development was done by dividing the resettlement area into four zones namely Kikwete Vision (Zone A), Nape (Zone B), Ridhiwani (Zone C) and Jakaya (Zone D). In each of the zones, the findings reveal that a significant number of plots which are yet to be devel- 
oped. For instance, in Zone A, which has a total of 287 plots, 213 plots have been developed while 74 plots, approximately $26 \%$ of all the plots are still vacant. In Zone B, 185 plots out of 243 are developed while 58 plots equivalent to $24 \%$ are yet to be developed. In Zone C, only 80 plots have been developed out of 151 total plots, and thus large proportion, 71 plots, equivalent to $47 \%$ are still vacant. In Zone D, large proportion, 285 plots out of 391, which is equivalent to $73 \%$ are yet to be developed.

While commenting on the existence of vacant plots, the households interviewed argued that such plots have been habitation places for hostile wild animals such as snakes which threaten the lives of the residents. The non-development of a large proportion of the plots allocated to the resettled households further underscores the challenge of self-financing of the house construction by the low income households. The undeveloped plots belong to resettled households or owners who either moved back to the original (displaced) settlements or resorted for rental accommodation in other parts of the city.

The Mabwepande housing development experience represent a typical disasters led state resettlement programme, which failed to consider livelihoods of the resettled individuals instead focused on the physical relocation through provisioning of just alternative land or plots. In contrary, experience of disaster led resettlement projects elsewhere shows that provisioning of housing solution is key for achieving sustainable urban development as well as poverty alleviation. The provisioning of housing can be achieved through participation and collaboration between the state and other developmental actors including the non-government and the private sector. Organising mechanisms for housing provisioning is vital taking into account financial constraints of both the state as well as the resettled individuals to finance the housing development after the resettlement. Cronin and Guthrie (2011) noted that a strong partnership approach between a community led NGO and communities overcame the political and financial hurdles in successful relocating a community devastated by annual floods to a newly constructed housing in Pure India. Ndezi (2009) also asserted that a strong collaboration between various actors including local NGOs, $\mathrm{Mu}$ nicipal authorities and the central government enabled development of alternative solutions for land and shelter to households displaced by a development project in Dar es Salaam.

\section{Conclusion}

The displacement of flood affected households from various parts of the city of Dar es Salaam followed few steps, which included identification of flood affected persons, establishment of temporary relocation centres, and finally transferring some of the victims to the resettlement area. By the end of the operation, about 680 families (3400 beneficiaries) were officially re-settled at Mabwepande. Although the floods affected both tenants as well as house owners, the resettlement only considered house owners who were accommodated in the temporary cen- 
tres and some who relocated to relatives and friends. The failure to integrate all affected persons into resettlement programmes means that those left out are forced to continue inhabiting informal or flood prone settlements in other parts of the city. As Wilmsen and Wang (2015) put forward one of the major criticisms of involuntary resettlement is that the projects are generally stand alone and not integrated into broader regional and national development plans, we argue that failure to include all affected households i.e. home owners and tenants emanates from unpreparedness and less integration of resettlement schemes in urban development plans. The study supports the recommendation put forward by Ndezi (2009) that in resettlement projects, national and local government agencies need to be flexible in addressing the needs of all the urban poor, including not only the owners of the structures in informal settlements but also the tenants.

Although the resettlement project involved a multiplicity of actors and stakeholders, lack of clear roles and coordination resulted in overlapping of the roles and responsibilities which culminated into power conflicts and unsustainability of the resettlement process. It is undisputable that resettlement schemes are costly if alternative land and houses have to be allocated to those resettled, public facilities have to be installed, and social services have to be provided. The paper has however demonstrated that, in order for a resettlement project to be successful, proper planning and provisioning of physical and social infrastructure facilities and services is prerequisite. The lack of clear mechanisms to ensure provisioning of housing and related infrastructure in the resettlement site has led to slow pace of house construction with majority of the households being accommodated in temporary shelters or under-construction and unfinished buildings due to inability to construct new and permanent houses. Failure to secure shelter in the resettlement site forced some of the resettled households to return back to the original, flood prone areas or seek alternative shelter in other informal settlements within the city. Access to some of basic facilities especially primary school, was also found to be a challenge resulting in long walking distances, school dropouts, pregnancies or early marriages.

One observation worth noting is that the displacement and resettlement project did not consider how to ensure improvement of the physical, social, and economic life of the resettled households, as the emphasis was on the provision of plots, and some of the basic infrastructure facilities. The provisioning of plots and few basic infrastructure facilities, without a broader consideration of the wider socio, economic, physical and cultural needs of the resettled households is what has is referred by Wilmsen and Wang to as a commitment to resettlement rather than a settlement (Wilmsen \& Wang, 2015). In as much as the various actors and stakeholders involved in the process ceased their assistance immediately after households were relocated and issued new plots, the resettled households had therefore to find their own ways and means of surviving after the ending of the government and other stakeholders support. 
To have a better resettlement outcome, it needs people centred practices that are embedded in policy, planning and implementation of poverty alleviation resettlement programmes, which are based on commitment to settlement and not just resettlement. Settlement is defined as the initial move and any transition period that occurs within the project cycle while settlement is a long-term commitment to supporting the resettled communities not only in securing shelter but also in improving the livelihoods and living standards of those displaced (ibid). Lack of sustainable programmes to support the resettled households to reconstruct their livelihoods, is a major reason for ineffective resettlement. Some of the households resettled to Mabwepande were reluctant to stay because of the uncertainties related to the livelihoods in the new settlement.

\section{Conflicts of Interest}

The authors declare no conflicts of interest regarding the publication of this paper.

\section{References}

Artur, L., \& Hilhors, D. (2014). Floods, Resettlement and Land access and Use in the Lower Zambezi, Mozambique. Land Use Policy, 36, 361-368.

Baird, I. G., \& Shoemaker, B. (2007). Unsettling Experiences: Internal Resettlement and International Aid Agencies in Laos. Development and Change, 38, 865-888. https://doi.org/10.1111/j.1467-7660.2007.00437.x

Boyko, C. T., \& Cooper, R. (2011). Clarifying and Re-Conceptualising Density. Progress in Planning, 76, 1-61. https://doi.org/10.1016/j.progress.2011.07.001

Chan, N. W. (1995). Flood Disaster Management in Malaysia: An Evaluation of the Effectiveness of Government Resettlement Schemes. Disaster Prevention and Management: An International Journal, 4, 22-29. https://doi.org/10.1108/09653569510093405

Conway, D. (2002). Extreme Rainfall Events and Lake Level Changes in East Africa: Recent Events and Historical Precedents. In E. O. Odada, \& D. O. Olago (Eds.), The East African Great Lakes. Limnology, Palaeolimnology and Biodiveristy (pp. 62-92). Dordrecht: Springer.

Correa, E. (2011). Populations at Risk of Disaster: A Resettlement Guide. Washington, DC: The World Bank. https://doi.org/10.1596/27383

Creswell, J. W. (2003). Research Design: Qualitative, Quantitative and Mixed Methods Approaches. Thousand Oaks, CA: Sage Publications.

Creswell, J. W. (2007). Qualitative Inquiry and Research Design: Choosing among Five Approaches (2nd ed.). Thousand Oaks, CA: Sage Publications.

Creswell, J. W. (2009). Research Design: Qualitative, Quantitative and Mixed Methods Approaches (3rd ed.). Thousand Oaks, CA: Sage Publications.

Cronin, V., \& Guthrie, P. (2011). Community-Led Resettlement: From a Flood Affected Slum to a New Society in Pune, India. Environmental Hazards, 10, 310-326.

https://doi.org/10.1080/17477891.2011.594495

Dawson, C. (2009) Introduction to Research Methods: A Practical Guide for Anyone Undertaking a Research Project (4th ed.). Oxford: How to Books.

De Folice, G. (2012). Reasoning with Mixed Qualitative-Quantitative Representations of 
Spatial Knowledge. Ph.D. Thesis, Bremen, Germany: University of Bremen.

Dixon, J., \& Ramutsindela, M. M. (2006). Urban Resettlement and Environmental Justice in Cape Town. Cities, 23, 129-139. https://doi.org/10.1016/j.cities.2005.08.003

Dublin City Council (2005). Dublin City Development Plan 2005-2011. Dublin, Ireland: Dublin City Council.

Dublin City Council (2011). Dublin City Development Plan 2011-2017. Dublin, Ireland: Dublin City Council.

Haile, A. T., Kusters, K., \& Wagesho, N. (2013). Loss and Damage from Flooding in the Gambela Region, Ethiopia. International Journal of Global Warming, 5, 483-497. https://doi.org/10.1504/ijgw.2013.057290

Handmer, J., Honda, Y., Kundzewicz, Z. W., Arnell, N., Benito, G., Hatfield, J., Mohamed, I. F., Peduzzi, P., Wu, S., Sherstyukov, B., Takahashi, K., \& Yan, Z. (2012). Changes in Impacts of Climate Extremes: Human Systems and Ecosystems. In C. B. Field, V. Barros, T. F. Stocker, D. Qin, D. J. Dokken, K. L. Ebi, M. D. Mastrandrea, K. J. Mach, G. K. Plattner, S. K. Allen, M. Tignor, \& P. M. Midgley (Eds.), Managing the Risks of Extreme Events and Disasters to Advance Climate Change Adaptation (pp. 231-290). Cambridge, New York: Cambridge University Press.

Holloway, A., Chasi, V., de Waal, J., Drimie, S., Fortune, G., Mafuleka, G., Morojele, M., Penicela Nhambiu, B., Randrianalijaona, M., Vogel, C., \& Zweig, P. (2013). Humanitarian Trends in Southern Africa: Challenges and Opportunities. Regional Interagency Standing Committee, Southern Africa. Rome: FAO.

http://reliefweb.int/sites/reliefweb.int/files/resources/Final_RIASCO_22July2013.pdf

John, R., Jean-Baptiste, N., \& Kabisch, S. (2014). Vulnerability Assessment of Urban Populations in Africa: The Case of Dar es Salaam-Tanzania. In E. Edgerton, O. Romice, \& K. Thwaites (Eds.), Bridging the Boundaries: Human Experience in the Natural and Built Environment and Implication for Research, Policy and Practice (pp. 233-245). Toronto: Hogrefe Publishing.

Korrea, E., Ramires, F., \& Sanahuja, H. (2011). Populations at Risk of Disaster A Resettlement Guide. Washington DC: The World Bank. https://doi.org/10.1596/27383 https://www.gfdrr.org/sites/gfdrr/files/publication/resettlement_guide_150.pdf

Lupala, J., \& John, R. (2012). Tracking the Process and Livelihoods of Kurasini Settlement Displacees in Dar es Salaam City, Tanzania. Rural Planning Journal, 14, 180-209.

Lwin, K. K., Murayama, Y., \& Mizutani, C. (2012). Quantitative versus Qualitative Geospatial Data in Spatial Modelling and Decision Making. Journal of Geographic Information System, 4, 237-241. https://doi.org/10.4236/jgis.2012.43028

Macaringue, J. (2010). Africa Climate Change Resilience Alliance (ACCRA). Mozambique, Country Level Literature Review.

Maghembe-Mushi, D. L., \& Lupala, J. M. (2015). Resettling Displaced Residents from Regularised Informal Settlements in Dar es Salaam, Tanzania: Challenges Faced by House Owners. Current Urban Studies, 3, 71-81. https://doi.org/10.4236/cus.2015.32007

Ndezi, T. (2009). The Limits of Community Initiatives in Addressing Resettlement in Kurasini Ward, Tanzania. Environment and Urbanisation, 21, 77-88. https://doi.org/10.1177/0956247809103005

Pafka, E. (2013). Nothing Gained by Only Counting Dwellings Per Hectare: A Hundred Years of Confusing Density (pp. 1-9). Sydney: State of Australian Cities Conference.

Reason, C., \& Keibel, A. (2004). Tropical Cyclone Eline and Its Unusual Penetration and 
Impacts over the Southern Africa Mainland. Weather and Forecasting, 12, 789-805. https://doi.org/10.1175/1520-0434(2004)019<0789:TCEAIU>2.0.CO;2

Scudder, T. (2012). Resettlement Outcomes of Large Dams. In C. Tortajada, D. Altinbilek, \& A. Biswas (Eds.), Impacts of Large Dams: A Global Assessment (pp. 37-67). Berlin: Springer-Verlag. https://doi.org/10.1007/978-3-642-23571-9_3

Scudder, T., \& Colson, E. (1982). From Welfare to Development: A Conceptual Framework for Analysis of Dislocated People. In A. Hansen, \& A. Ohver-Smith (Eds.), InvoIuntary Migration and Resettlement. Boulder: West View Press.

Stake, R. E. (2010). Qualitative Research: Studying How Things Work. New York: Guilford Publications, Inc.

Stal, M. (2011). Flooding and Relocation: The Zambezi River Valley in Mozambique. International Migration, 49, e125-e145. https://doi.org/10.1111/j.1468-2435.2010.00667.x

UNDRR (2019). Global Assessment Report on Disaster Risk Reduction. Geneva, Switzerland: United Nations Office for Disaster Risk Reduction (UNDRR).

UN-HABITAT (2008). United Nations, State of the World's Cities 2008/09-Harmonious Cities. Nairobi, Kenya: United Nations Human Settlement Programme.

UNISDR (2015). Global Assessment Report on Disaster Risks Reduction. Making Development Sustainable: The Future of Disaster Risk Reduction. New York: United Nations. https://www.unisdr.org/we/inform/gar

United Nations Environment Programme (UNEP) (2012). Early Warning Systems: A State of the Art Analysis and Future Directions. Nairobi: UNEP.

Wilmsen, B., \& Wang, M. (2015). Voluntary and Involuntary Resettlement in China: A False Dichotomy? Development in Practice, 25, 612-627.

https://doi.org/10.1080/09614524.2015.1051947

World Health Organization (WHO) (2007). Mozambique Flood Preliminary Report. Geneva, Switzerland: World Health Organization.

http://www.who.int/hac/crises/moz/sitreps/mozambique_floods_report1_21feb2007

Yin, R. K. (2014). Case Study Research Design and Methods (5th ed., 282 p.). Thousand Oaks, CA: Sage. https://doi.org/10.3138/cjpe.30.1.108 